IZA DP No. 5378

Progressive Taxation and Tax Morale

Philipp Doerrenberg

Andreas Peichl

December 2010

Forschungsinstitut

zur Zukunft der Arbeit

Institute for the Study

of Labor 


\title{
Progressive Taxation and Tax Morale
}

\author{
Philipp Doerrenberg \\ CGS, University of Cologne \\ Andreas Peichl \\ IZA Bonn, University of Cologne, \\ ISER and CESifo
}

\section{Discussion Paper No. 5378 December 2010}

\author{
IZA \\ P.O. Box 7240 \\ 53072 Bonn \\ Germany \\ Phone: +49-228-3894-0 \\ Fax: +49-228-3894-180 \\ E-mail: iza@iza.org
}

\begin{abstract}
Any opinions expressed here are those of the author(s) and not those of IZA. Research published in this series may include views on policy, but the institute itself takes no institutional policy positions.

The Institute for the Study of Labor (IZA) in Bonn is a local and virtual international research center and a place of communication between science, politics and business. IZA is an independent nonprofit organization supported by Deutsche Post Foundation. The center is associated with the University of Bonn and offers a stimulating research environment through its international network, workshops and conferences, data service, project support, research visits and doctoral program. IZA engages in (i) original and internationally competitive research in all fields of labor economics, (ii) development of policy concepts, and (iii) dissemination of research results and concepts to the interested public.
\end{abstract}

IZA Discussion Papers often represent preliminary work and are circulated to encourage discussion. Citation of such a paper should account for its provisional character. A revised version may be available directly from the author. 
IZA Discussion Paper No. 5378

December 2010

\section{ABSTRACT}

\section{Progressive Taxation and Tax Morale}

As the link between tax compliance and tax morale is found to be robust, finding the determinants of tax morale can help to understand and fight tax evasion. In this paper we analyze the effect of progressive taxation on tax morale in a cross-country approach - which has not been investigated before. Our theoretical analysis leads to two testable predictions. First, an individual's tax morale is higher, the more progressive the tax schedule is. Second, the impact of tax progressivity on tax morale is declining in income. In our empirical analysis, we make use of a unique dataset of tax progressivity measures and follow most of the tax morale literature by employing the World Values Survey to measure tax morale. Controlling for a wide range of variables, we confirm both hypotheses in our empirical analysis.

JEL Classification: $\quad H 26, H 24$, D7, D31

Keywords: tax morale, tax compliance, progressivity, taxation, redistribution

Corresponding author:

Andreas Peichl

IZA

P.O. Box 7240

53072 Bonn

Germany

E-Mail: peichl@iza.org

\footnotetext{
* Andreas Peichl is grateful for financial support from the Deutsche Forschungsgemeinschaft DFG. We are grateful to Klara Peter and Denvil Duncan for sharing their data. We would like to thank Clemens Fuest, Judith Niehues and Michael Thoene for helpful suggestions and comments.
} 


\section{Introduction}

The problem of tax evasion has existed ever since taxes themselves came into being. Evasion has been and still is a considerable problem in almost all societies and countries. For example, the United States Department of the Treasury and the Internal Revenue Service have estimated that the overall net tax gap for the USA in 2001-measuring the difference between tax-paying obligations and voluntarily paid taxes - was $\$ 290$ billion. This equates to a share of $13.7 \%$ of all taxes that should have been paid (reported in Slemrod 2007). Based on the economics-of-crime approach by Becker (1968), the standard approach of modeling tax evasion decisions assumes a simple expected-utility maximization problem, where tax evasion pays off but is risky because of penalties when detected (Allingham and Sandmo 1972). The model, however, does not explain satisfactorily the observed degrees of tax compliance, as feeding it with actual figures of detection probabilities and penalty fees yields considerably more evasion than observed in reality (Alm et al. 1992, Slemrod and Yitzhaki 2002). High levels of risk aversion are not able to explain high compliance within standard models either (Frey and Feld 2002). Experimental research also confirms that the standard approach is not appropriate to explain tax evasion behavior (Torgler 2002). ${ }^{1}$

Economists have recently started to work on reasons for high compliance and revealed that tax morale - usually defined as the intrinsic motivation to pay taxes which arises from the moral obligation to pay taxes as a contribution to society (see, e.g., Feld and Frey 2007, Torgler 2007, Alm and Gomez 2008, Cummings et al. 2009)_plays a significant role in explaining observed tax evasion behavior. Among others, cross-country analyses by Richardson (2006) and Torgler et al. (2008) find strong and significant support for a negative relationship of tax morale and tax evasion. Other authors investigate the impact of variables on tax evasion, which in the literature were found to shape tax morale, and also find a close link between tax morale and tax compliance (Erard and Feinstein 1994, Pommerehne and WeckHannemann 1996, Wu and Teng 2005, Cummings et al. 2009). ${ }^{2}$ In a cross-country analysis Alm and Torgler (2006) find statistically significant evidence that higher tax morale leads to smaller shadow economies. Results pointing in the same direction have also been found in many other empirical analyses (see, among others, Torgler 2005, Alm et al. 2006, Dell'Anno 2009 and Torgler and Schneider 2009). Based on his empirical findings, Halla (2010) concludes that 1) economic scholars need to be

\footnotetext{
${ }^{1}$ Refer to Andreoni et al. (1998) for a comprehensive overview on tax evasion literature.

${ }^{2}$ Most of the mentioned analyses employ the World Values Survey to measure tax morale. We use the very same data source for our empirical analysis.
} 
interested in the determinants of tax morale because it unambiguously affects actual tax compliance behavior and 2) policy makers can alter tax evasion by manipulating tax morale.

As the link between tax evasion and tax morale has been shown to be robust, finding determinants of tax morale can help to understand and fight actual tax evasion. In this paper we contribute to the literature by investigating the impact of progressive taxation on individual tax morale which has - to the best of our knowledge - not been investigated before. Standard economic approaches would predict that progressive taxes increase the tax morale of those who are financially better off under such a system, whereas it lowers the tax morale of those not benefiting in comparison with, say, a linear tax system. However, considering empirical research results that many individuals seem to be averse to inequality and that redistribution is predominantly supported across the population, we consider the relation between tax morale and progressive taxes to be less straight-forward. We set up a theoretical model of tax progressivity with inequality averse individuals following Fehr and Schmidt (1999) and derive two testable hypotheses, which we investigate by employing an empirical approach using micro-level survey data for individual tax morale from the World Value Survey (WVS) and contextual data for tax progressivity from Peter et al. (2010).

Our theoretical analysis shows that that all members of the middle-class and the poor unambiguously benefit from an increase in tax progressivity, whereas for a rich person her utility might also rise if she is sufficiently averse towards inequality. This leads to two testable predictions. First, an individual's tax morale is higher, the more progressive the tax schedule is. Second, the impact of tax progressivity on tax morale is declining in income. Controlling for a wide range of variables, we confirm both hypotheses in our empirical analysis.

The proceeding of the paper is as follows: In section 2 we review related literature on the determinants of tax morale. In section 3 we examine theoretical considerations relating to our research question and present our hypothesis. Section 4 describes the empirical. The results are presented in section 5 and section 6 concludes.

\section{The Determinants of Tax Morale}

The determinants of tax morale have been analyzed by using either experimental or empirical survey data. We focus on survey based evidence because we employ 
survey data in our empirical analysis ourselves. ${ }^{3}$

Socio-demographic Variables Almost all empirical analyses indicate that the elderly tend to have a higher tax morale and that women have a higher tax morale than men. These effects seem to be very robust and were found for many countries, including Western industrialized countries (Slemrod 2003, Alm and Torgler 2006, Frey and Torgler 2007, Konrad and Qari 2009), Latin American countries (Torgler 2005), Asia (Torgler 2004) and Russia (Alm et al. 2006). Torgler (2006) includes a very broad range of countries from different cultures in his regressions and also finds accordant results. Tittle (1980), for example, provides reasons for this by arguing that old people are more experienced and thus more sensitive to social sanctions. Considering the historic role of women, Tittle stresses that they are more compliant and less self-reliant than men. Furthermore, most empirical research on tax morale finds that married people develop a higher tax morale than singles (Alm and Torgler 2006, Torgler 2006, Frey and Torgler 2007, Konrad and Qari 2009). The intuition behind this, however, is ambiguous. Tittle (1980) stresses that it is due to higher social constraints of married people, whereas Torgler (2007) notes that the differences might occur due to different treatments of married people in the tax system.

Socio-economic Variables Intuitively, the impact of income on tax morale is not clear. On the one hand, evasion yields higher returns for high-income earnersespecially in countries with progressive tax systems. On the other, people earning high incomes might have higher societal stakes and are more affected by sanctions, i.e. losing a well-paid job. Accordingly, the empirical picture is ambiguous as well. Whereas Konrad and Qari (2009) cannot find any significant effects using European data, a negative relationship is found by Torgler (2004) for Asian countries, Alm and Torgler (2006) for Europe and the USA, and Torgler (2006) for a large sets of different countries. When it comes to the occupation status, almost all findings indicate that the self-employed to have a lower tax morale than other occupation groups (see Alm and Torgler 2006, Frey and Torgler 2007 or Konrad and Qari 2009 for Europe; Torgler 2004 for Asia; or Alm et al. 2006 for Russia). Theoretical explanations are very intuitive: taxes are more visible to the self-employed and there are more opportunities to evade compared to employees. In contrast, the impact of education on tax morale should be ambiguous: educated people tend to know better what the state provides and how it spends collected tax revenues. Hence, tax morale among the educated should vary depending on the state's spending

\footnotetext{
${ }^{3}$ Refer to Torgler (2002) for a detailed overview of experimental results.
} 
efficiency (Torgler 2007). When controlling for state efficiency parameters, however, a large fraction of the survey literature finds positive impacts in both developing and industrialized countries (Alm and Gomez 2008 for Spanish data; Konrad and Qari 2009 for Europe; or Torgler 2005 for Latin America, among others). Other authors, nevertheless, find non-significant or even negative effects (e.g. Frey and Torgler 2007 or Alm et al. 2006).

Trust in Government and National Pride A major focus in tax morale research is on perceived trust in state functioning or public finance. The intuition is obvious: taxpayers who trust their government and believe that tax revenue is spent properly should be more willing to pay taxes. In contrast, tax morale decreases as people believe that tax money is spent redundantly - a notion supported by survey research. For example, Slemrod (2003) and Frey and Torgler (2007) use data for Europe and find significant and positive effects of different "trust in state" variables on tax morale. Their results are confirmed for other countries and cultures, such as Spain (Alm and Gomez 2008), Asia (Torgler 2004), Latin America (Torgler 2005) and Russia (Alm et al. 2006). Another closely related variable is national pride. Using a similar intuition, taxpayers who are proud of their country of residence may well be more willing to pay taxes. Konrad and Qari (2009) employ a cross-country analysis on several European countries and find strong evidence that patriotism does indeed have a positive effect on tax morale. Similar results are found for Latin America (Torgler 2005), Asia (Torgler 2004) and Russia (Alm et al. 2006).

Religion Empirical research on crime behavior by Hull (2000) reveals that delinquent behavior and religious beliefs are negatively related. Torgler (2006) conducts an extensive investigation on this relationship and finds a strong causal relationship between different variables capturing religiosity and tax morale. The results are confirmed by Konrad and Qari (2009) for European countries and Torgler (2005) for Latin America.

Macro-economic Indicators The impact of macro-economic indicators such as GDP, inflation or unemployment rate on tax morale has so far not been sufficiently analyzed sufficiently. One exception, however, is Heinemann (2010), who analyzes whether an economic crisis - measured as a short-run jump in unemployment-has an impact on tax morale. His results reveal that the crisis variable unfolds a significant and negative effect on tax morale, indicating that tax morale is lower during a crisis. A few other authors have included macro-economic indicators as controls in their regressions. Slemrod (2003), for example, includes the share of government 
expenditure of GDP in his analysis and finds that tax morale decreases as relative government expenditures rise. Martinez-Vazquez and Torgler (2009) analyze tax morale in Spain and find that both the unemployment rate and inflation-measured on the regional level - are negatively related to tax morale. Interesting for our purposes are the experimental results by Heinemann and Kocher (2010), who observe that tax compliance is higher in progressive tax systems than in linear ones.

\section{Theoretical Considerations}

\subsection{Attitudes towards Redistribution and Progressive Tax- ation}

Clearly, the impact of progressive taxes on individual tax morale depends on individual attitudes towards both redistribution in general and progressive taxation in particular. Standard economics, emphasizing selfishness only, would predict that attitudes towards both are supported by those benefiting monetarily and disliked by those who are net payers. However, although in most democratic countries the number of net contributers outweighs the number of net recipients, progressive taxes are usually in force.

Factors shaping attitudes towards redistribution are analyzed by Fong (2001) using survey data. The results unambiguously suggest that income is a poor predictor of support for redistribution and that redistribution is not only supported by those who benefit from such a system. Corneo and Gruener (2002) employ an empirical cross-country analysis and confirm that the standard economic model is only partly able to explain individual support for redistribution. These results are strongly supported by other works in this field. Alesina and Giuliano (2009) provide an extensive review of existing literature. Their findings clearly indicate that income is a poor explanation for support of redistribution and that redistribution is a majority preference.

Literature on attitudes towards progressive taxation in particular contains similar results. For Germany, Heinemann and Hennighausen (2010) show that personal income concerns are only partly able to explain support for progressive taxation. According to their findings, both the own income situation and fairness aspects play a role when progressive taxation is evaluated. Ackert et al. (2007) conduct experiments to examine whether individuals are driven by inequality aversion when choosing between different taxes. Their results reveal that in most cases the majority votes for the progressive tax and that it is not necessarily a median voter-being indifferent in monetary terms - who is decisive. A share of the richest players al- 
ways votes for the progressive tax, although they suffer from it in terms of monetary after-tax income.

The above results on attitudes towards redistribution and progressive taxation might indicate that individuals do not only care about their own well-being, but also about other people's. The results observed in experimental games such as the ultimatum game (Gueth et al. 1982) or the dictator game (Kahneman et al. 1986) support this observation and suggest that most individuals behave less selfishly and behave more compassionately than widely thought. ${ }^{4}$ Hence, evidence is strong that besides their own pay-off, individuals also attach importance to decently fair distributions.

\subsection{A Model of Inequality Aversion}

In order to show the effect of tax progressivity on individuals having preferences of inequality aversion, we make use of a model developed by Fehr and Schmidt (1999) (henceforth: F\&S). F\&S set up a model of self-centered inequality aversion, in which inequality aversion means that individuals dislike inequitable outcomes and self-centered indicates that this aversion primary stems from a comparison of their own and other people's pay-offs. In particular, it is assumed that individuals derive utility from their own income situation but suffer from inequality in terms of being either better or worse off in material terms than other individuals. They, however, dislike being worse off than others more than being better off. Equation 1 shows how this intuition is translated into a formal model. In an environment with $n$ players the F\&S utility function of individual $i \in(1, \ldots, n)$ writes as

$$
U_{i}(x)=x_{i}-\alpha_{i} \frac{1}{n-1} \sum_{j \neq i} \max \left(x_{j}-x_{i}, 0\right)-\beta_{i} \frac{1}{n-1} \sum_{j \neq i} \max \left(x_{i}-x_{j}, 0\right) .
$$

An individual $i$ 's utility positively depends on her own income $x_{i}$ and is negatively related to the difference between her income and that of other people's $j$. The second term expresses how someone dislikes being worse off than others, while the third term shows disutility from being better off than others. Based on experimental observations, the following parameter restrictions apply: $\alpha_{i} \geq \beta_{i} \geq 0$ indicates than an individual $i$ 's utility loss from disadvantageous inequality $\left(x_{i}<x_{j}\right)$ is larger than from advantageous inequality $\left(x_{i}>x_{j}\right)$. By normalizing terms 2 and 3 with $n-1$, it is ensured that the impact of inequality aversion on $i$ 's utility is independent from the number of players $n$. In accordance with experimental evidence, Fehr and

\footnotetext{
${ }^{4}$ See Konow (2003) and Fehr and Schmidt (2006) for overviews on compassionate behavior.
} 
Schmidt (1999) explicitly allow individuals to be heterogeneous, so that some people are purely selfish $(\alpha=\beta=0)$ and others might have strong aversions towards both advantageous and disadvantageous inequalities. The F\&S model is very powerful insofar as it is able to explain the outcomes of a wide range of experimental results and hence describe human behavior more appropriately than the standard model of selfish preferences. ${ }^{5}$

\subsection{Progressive Taxation in the F\&S Framework}

\subsubsection{Adapting the F\&S Framework}

In order to be able to adapt the $\mathrm{F} \& \mathrm{~S}$ framework of inequality aversion, we assume each individual $i \in(1, \ldots, N)$ to be a member of either one of three income classes: The rich, middle and poor income class $\mathrm{c}$ with $c \in(r, m, p)$. We further assume that $n_{r}$ people are rich, $n_{m}$ people belong to the middle-class and $n_{p}$ people are poor, and so $n_{r}+n_{m}+n_{p}=N$. For reasons of simplicity, all members within one income class have the same exogenous income. ${ }^{6}$ The rich and middle-class individuals have incomes of $x_{r}$ and $x_{m}$, respectively, with $x_{r}>x_{m}>0$. Initially, the members of the poor income class do not have income, i.e. $x_{m}=0$. We assume positive but decreasing marginal utility of income. Both rich and the middle-class members have to pay tax rates $t_{r}$ and $t_{m}$, respectively, on their income. ${ }^{7}$ The tax system is assumed to be progressive, so that $t_{r}>t_{m}$. Hence, individuals in the rich and middle-classes have net incomes $x_{r}^{N}=x_{r}-t_{r} x_{r}=x_{r}\left(1-t_{r}\right)$ and $x_{m}^{N}=x_{m}-t_{m} x_{m}=x_{m}\left(1-t_{m}\right)$. Members of the poor income class do not earn income, and hence do not pay taxes, but receive the taxes paid by members of the other income classes as benefits. Thus, each individual in the poor income-class has net income $x_{p}^{N}=\frac{1}{n_{p}}\left(n_{r} t_{r} x_{r}+n_{m} t_{m} x_{m}\right)$. A final assumption holds that the order of gross incomes remains the same after taxes, yielding: $x_{r}^{N}>x_{m}^{N}>x_{p}^{N}$. The utility functions are based on inequality averse F\&S preferences:

$$
\begin{gathered}
U_{i}\left(x_{r}^{N}\right)=\ln \left(x_{r}^{N}\right)-\beta_{i} \frac{1}{N-n_{r}}\left[n_{m}\left(x_{r}^{N}-x_{m}^{N}\right)+n_{p}\left(x_{r}^{N}-x_{p}^{N}\right)\right], \\
U_{i}\left(x_{m}^{N}\right)=\ln \left(x_{m}^{N}\right)-\alpha_{i} \frac{1}{N-n_{m}} n_{r}\left(x_{r}^{N}-x_{m}^{N}\right)-\beta_{i} \frac{1}{N-n_{m}} n_{p}\left(x_{m}^{N}-x_{p}^{N}\right),
\end{gathered}
$$

\footnotetext{
${ }^{5}$ See the original paper or Eckel and Gintis (2010) for a recent overview.

${ }^{6}$ It is important to note that individual preferences on inequality will not be equal among members of one income class.

${ }^{7}$ The taxes do not create any distortions because of the presence of exogenous income.
} 


$$
U_{i}\left(x_{p}^{N}\right)=\ln \left(x_{p}^{N}\right)-\alpha_{i} \frac{1}{N-n_{p}}\left[n_{r}\left(x_{r}^{N}-x_{p}^{N}\right)+n_{m}\left(x_{m}^{N}-x_{p}^{N}\right)\right] .
$$

As in F\&S, we assume $\beta_{i} \leq \alpha_{i}$ and $0 \leq \beta_{i}<1$. Since all members within one income class have the same income, there are no inequalities towards members of the same income class. $\ln \left(x_{c}\right)$ accounts for positive but decreasing marginal utility of income. The rich do not have to face disadvantageous inequalities, whereas each poor individual is poorer than individuals in each of the other income classes and hence only faces disadvantageous inequalities. The middle-class individuals, as they are richer than the members of the poor income class but poorer than individuals in the rich income class, face both kinds of inequality.

\subsubsection{Increase in Progressivity}

Considering our research question, we are interested in the effect of progressivity on people's utilities. We model an increase in progressivity by a rise in the tax rate on rich incomes $t_{r}$, whereas the middle-class tax rate $t_{m}$ remains constant. Using $\frac{\partial x_{r}^{N}}{\partial t_{r}}=-x_{r}<0, \frac{\partial x_{m}^{N}}{\partial t_{r}}=0$ and $\frac{\partial x_{p}^{N}}{\partial t_{r}}=\frac{n_{r}}{n_{p}} x_{r}>0$ yields for the derivatives of equations $2-4$ :

$$
\begin{gathered}
\frac{\partial U_{i}\left(x_{r}^{N}\right)}{\partial t_{r}}=\frac{1}{x_{r}^{N}}\left(-x_{r}\right)+\beta_{i} x_{r} \frac{N}{N-n_{r}}, \\
\frac{\partial U_{i}\left(x_{m}^{N}\right)}{\partial t_{r}}=\frac{n_{r}}{N-n_{m}} x_{r}\left(\alpha_{i}+\beta_{i}\right)>0, \\
\frac{\partial U_{i}\left(x_{p}^{N}\right)}{\partial t_{r}}=\frac{n_{r}}{n_{p}} x_{r}\left(\frac{1}{x_{p}^{N}}+\alpha_{i} \frac{N}{N-n_{p}}\right)>0 .
\end{gathered}
$$

The results imply that all members of the middle-class and the poor-class unambiguously benefit from an increase in $t_{r}$. The intuition is straight-forward, which is the middle-class individuals gain utility through two different channels: 1) the disadvantageous utility towards the rich individuals decreases as their own income remains stable and the rich individuals' net income becomes smaller, and 2) as the poor individuals are now richer because of higher benefits, the middle-class' advantageous inequality reduces as well. The poor benefit from three positive effects: 1) their net-income increases through higher benefits, 2) inequality towards the middle class decreases because they themselves become richer and the middle-class keep their income, and 3) inequality towards the rich individuals strongly reduces as the rich's higher tax burden solely benefits the poor. However, the impact on a rich individual's utility is not clear and depends on $\beta_{i}$. Intuitively, there are two 
countervailing effects in force: 1) their net income decreases, as they have to pay more taxes, and 2) the degree of advantageous inequality towards both the poor and the middle-class decreases. Based on equation 5, one can see that the rich individuals's utility $U_{i}\left(x_{r}^{N}\right)$ increases after the increase in progressivity if

$$
\beta_{i}>\frac{N-n_{r}}{N} \frac{1}{x_{r}^{N}}=\frac{N-n_{r}}{N} \frac{1}{x_{r}\left(1-t_{r}\right)} .
$$

That is, if a rich person $i$ is sufficiently averse towards advantageous inequality, her utility might also rise as a result of the increase in the tax schedule's progressivity. Derived from a wide range of different outcomes in game experiments, Fehr and Schmidt (1999, page 844, Table III) provide rough numerical estimates for the parameters in their model. They suggest that $30 \%$ of all individuals do not care for advantageous inequalities at all $(\beta=0)$, while another $30 \%$ are moderatly averse to advantageous inequalities. The largest share of the population, at $40 \%$, however, is believed to to be highly averse to advantageous inequality. Other authors have also tried to estimate numerical values for the parameters $\alpha$ and $\beta$ that fit real economic behavior (see Eckel and Gintis 2010 for a recent overview). Bellemare et al. (2008) use a large, representative sample of the Dutch population and find that on average the population seems to be even more averse towards both advantageous and disadvantageous inequality than is assumed by Fehr and Schmidt (1999). Those results - providing evidence that $\alpha$ and $\beta$ seem to be very high - might indicate that a very large fraction of the rich individuals in our model is indeed in favor of higher progressive taxation.

\subsection{Hypotheses}

Hypothesis 1 An individual's tax morale is higher, the more progressive the tax schedule is, ceteris paribus.

Our main hypothesis is primarily based on two arguments we derived in the previous sections. First, the comprehensive literature on redistribution finds strong empirical cross-country evidence supporting redistribution and progressive taxation as a majority preference. Attitudes towards both redistribution and progressive taxation do not solely depend on whether an individual suffers or benefits in monetary terms. Often individuals who lose money through redistribution and progressive taxes are in favor of such mechanisms. Second, we showed formally how progressive taxation affects inequality averse individuals' utility. Our theoretical model suggests that people belonging to the poor and middle income classes unambiguously benefit in terms of utility. However, although they lose most in monetary terms, even a large 
share of the rich population is in favor of progressive taxes. Assuming that people are more willing to pay taxes in systems that provide them with more utility, we hypothesize that progressive taxes increase tax morale and therefore tax compliance as well.

Hypothesis 2 The positive impact of progressive taxation on individual tax morale declines in income, ceteris paribus.

Our second hypothesis builds on our theoretical analysis showing that the rich income class faces two opposing effects caused by higher progressive taxation. They lose in monetary terms because their tax burden increases, but benefit through less inequality compared to the other income classes. Furthermore, our theory predicts that the middle-class benefit through two different channels, whereas the poor-class increase their utility through even three positive effects. Considering these results, we expect the impact of progressivity to decline in income.

\section{Empirical Approach}

\subsection{Data Sources}

All individual-level variables are derived from the World Values Survey (WVS) and the European Values Survey (EVS). WVS/EVS is the most common data source in tax morale research. It is a worldwide survey which collects comparative data on many different values and attitudes using standardized questionnaires for representative national samples of at least 1000 respondents per country (Inglehart n.d.). The surveys are conducted by professional scientific institutions and performed through face-to-face interviews at the respondents' home and in their respective national language. ${ }^{8}$ We employ an integrated data file provided by the WVS data archive in collaboration with EVS (EVS/WVS 2006) and make use of all four waves included in the data file. Waves 1, 2, 3 and 4 were carried out between 1981-1984, 1989-1993, 1994-1998, 1999-2004, respectively. Our analysis is restricted to relative homogeneous OECD countries. Due to missing data ${ }^{9}$ some of the OECD countries had to be excluded. In the end, 19 countries remain in the analysis: Austria, Belgium, Canada, Denmark, Finland, France, Germany, Hungary, Iceland, Ireland, Italy, Japan, Mexico, the Netherlands, Norway, Spain, Sweden, the United Kingdom

\footnotetext{
${ }^{8}$ Inglehart (2000) provides more comprehensive information on the WVS.

${ }^{9}$ Missings are due to: 1) a few countries do not have data for the first wave on the country level, and 2) some countries have been included in only one of the waves. These had to be excluded in order to obtain sufficient variation within countries and across points of time.
} 
and the USA. Not all countries are to be found in each wave, so we do not have 19 (countries) $* 4$ (points of time $)=76$ observations at the country level, but only 50 . Table 3 in the appendix provides an overview.

The country-level tax measures are derived from the World Tax Indicators (WTI) (Peter et al. 2010). This large and rather new panel data set covers personal income tax structures at the country level in 189 countries for the period 1981 to 2005. As it contains the complete national income tax structures, including statutory rates, tax brackets, country-specific tax formulae, basic allowances, standard deductions and local taxes, among others, the data allow the analysis of various important variables such as average and marginal tax rates, progressivity or complexity. The data were collected from more than 100 sources including publications by accounting firms or data sets of international organizations and public policy research institutions (Peter et al. 2010). In addition to the WTI, we also make use of the World Bank's World Development Indicators in order to obtain other country-level data. The data cover a wide range of macro-economic information for more than 200 countries for each year since 1960 (World Bank 2010).

\subsection{Operationalization}

\subsubsection{Dependent Variable: Tax Morale}

Our dependent variable tax morale is measured on the micro-level and is derived from the WVS. The respective question covering tax morale is:

Please tell me for the following statement whether you think it can always be justified, never be justified, or something in between: 'Cheating on taxes if you have the chance'.

This question has been used very frequently in the literature to capture tax morale. However, it is of course not free of bias. As for example noted by Andreoni et al. (1998), people might overstate their degree of morality in self-reports such as the WVS and those who have evaded might want to excuse their behavior by declaring a high tax morale. Elffers et al. (1987) find that there are significant differences between actual tax evasion and self-reported tax evasion in surveys. Nevertheless, asking about tax morale is less blunt than asking about tax evading behavior, and so the degree of honesty should be higher (Frey and Torgler 2007). Another shortcoming of the question refers to the fact that taxpayers might find tax evasion justifiable if tax revenue is used for, say, financing a dictator's war machine (Frey and Torgler 2007). We consider this problem by restricting the analysis to relative homogeneous and democratic OECD countries and by controlling for individual trust in the state. 
Previous robust evidence shows that low WVS levels of tax morale are associated with high tax evasion and vice versa. Hence, we believe that it is appropriate to measure tax morale with this question.

In the WVS the question is measured on a ten-scale index with "never justified" and "always justified" at the extremities. In line with other empirical studies on tax morale, such as Alm and Torgler (2006) and Heinemann (2010), we recode the variable so that it takes the values 1 for "never justified" and 0 otherwise. This approach is due to the fact that many respondents assert that cheating on taxes is "never justified".

\subsubsection{Main Explanatory Variable: Tax Progressivity}

As we analyze the impact of progressive taxes on individual-level tax morale, we require a progressivity measure that is perceivable to most people. Hence, we need a measure of tax progressivity that is derived from the tax schedule itself. The World Tax Indicators (Peter et al. 2010) is the first comparable and reliable cross-country data set that provides a single measure for the overall progressivity of a tax schedule's progressivity. In the WTI average rate progression (ARP) is calculated as follows: ${ }^{10}$ average tax rates for each country and year in the data set are first computed for 100 evenly spread pre-tax incomes. ARP is then constructed by regressing tax rates on the log of gross income. The tax system is progressive, proportional and regressive if the resulting slope coefficient of the income variable is positive, zero or negative, respectively. Hence, the degree of progressivity is higher, the larger the positive slope coefficient.

\subsubsection{Other Explanatory Variables}

As section 2 shows, there is a wide range of independent variables found to have an impact on tax morale. In order to isolate the effect of progressive taxes, these variables need to be controlled for. As we have already discussed the theoretic and previously found effects, we do not go into details here but ask the reader to refer to table 2 in the appendix for details of measurement and operationalization. Following our theoretical analysis, we transform the WVS income variable so that three income classes can be distinguished: the poor, middle and rich. We further need to control for the general tax burden because it is very likely to be positively correlated with tax progressivity, as welfare states employing much redistribution often have high levels of taxes. Unfortunately, data on an individual's income tax rate are not available in the WVS. Using the WTI, we proxy the overall tax burden by including the

\footnotetext{
${ }^{10}$ See Peter et al. (2010, pp. 462-465) for more comprehensive information.
} 
tax rate applicable to the highest income bracket in each country in our regression. We control for culture and country-specific effects by including dummy variables for every country but one. This is very important in cross-country analyses of moral standards, as it allows the isolation of the main explanatory variable from the general level of morale, which might vary across countries. Furthermore, we include several macro-economic indicators derived from the World Development Indicators: unemployment rate, GDP per capita, annual consumer price inflation rate, and government expenditure as a share of GDP. By including these, we are able to control for the economic environment in each country at each point of time. Table 2 in the appendix summarizes all variables included in the model.

\subsection{Estimation strategy}

Our data set pools together randomly drawn samples in each country at different points of time. Generally, we relate country-level progressivity to individual tax morale. In order to account for unobservable country and time-specific effects, we include time and country dummies and thus take advantage of cross-country and time variations in progressivity. We employ a binary logistic regression to account for the dichotomous character of the dependent variable, tax morale. The model contains both individual and contextual (country) level variables as regressors. Recognizing that the inclusion of country level variables might cause error terms not to be independent and uncorrelated, we report robust standard errors that account for clustering of individuals within one country at a certain point of time (Moulton 1986). The logit model we estimate to test our first hypothesis takes the form: ${ }^{11}$

$\ln \left(\frac{\operatorname{Pr}\left(T M_{c, i, t}=1\right)}{\operatorname{Pr}\left(T M_{c, i, t}=0\right)}\right)=i n t+\beta_{1} T P_{c, t}+I C_{c, i, t}+M C_{c, t}+\sum_{c=2}^{C} C D_{c}+\sum_{t=2}^{W} W D_{t}+\epsilon_{c, i, t}$.

$T M$ stands for the dummy variable tax morale, $T P$ indicates tax progressivity, $I C$ represents a vector of variables on the individual level and the respective coefficients, $M C$ is a vector of country level variables and their respective coefficients. $C D$ and $W D$ are country and wave dummy variables. The dependent variable is the logarithmized odd to have high tax morale. The tax morale of an individual $i$ in country $c$ at point of time $t$ depends on several individual, time and country factors. The equation shows that our main explanatory variable, tax progressivity, differs across countries and points of time but not across individuals who live in

\footnotetext{
${ }^{11}$ Alesina et al. (2004), McKinnish (2007) and Heinemann (2010), among others, employ very similar empirical approaches and estimation techniques.
} 
the same country and participated in the survey at the same point of time. Each individual in a certain country $c$ at a certain point of time $t$ faces the same degree of progressive taxes. The same holds for the macro variables, but not for the individual ones. As mentioned, dummies for all, bar one wave and country, are included to capture country and time specific effects. Hence, $C$ in the equation is the number of included countries and $W$ the number of waves, int captures the intercept which is barely interpretable in logistic regression and $\epsilon_{c, i, t}$ is a standard error term. Our coefficient of interest, $\beta_{1}$, measures the impact of tax progressivity on individual tax morale. The interpretation is as follows: the logarithmized odd to have high tax morale increases by $\beta_{1}$ if the degree of progressivity increases by one unit.

In order to be able to test our second hypothesis, we add interaction terms between our measure of progressivity and the three income groups to the above model. The model then transforms to:

$$
\begin{array}{r}
\ln \left(\frac{\operatorname{Pr}\left(T M_{c, i, t}=1\right)}{\operatorname{Pr}\left(T M_{c, i, t}=0\right)}\right)=i n t+\beta_{1} T P_{c, t}+\beta_{2}\left(T P_{c, t} * M C_{c, i, t}\right)+\beta_{3}\left(T P_{c, t} * R C_{c, i, t}\right) \\
+I C_{c, i, t}+M C_{c, t}+\sum_{c=2}^{C} C D_{c}+\sum_{t=2}^{W} W D_{t}+\epsilon_{c, i, t},
\end{array}
$$

where $M C$ and $R C$ stand for the middle-class and the rich-class, $\beta_{1}$ now is the impact of progressive taxation on tax morale among the poor income class, $\beta_{1}+\beta_{2}$ indicates the impact of individuals in the middle-class, and $\beta_{1}+\beta_{3}$ represents the effect of progressivity among the rich.

\section{Results}

\section{$5.1 \quad$ Regression Results}

Our results are presented in table 1 . We show the usual coefficients of the logistic regression, which allows the interpretation of the signs of the coefficients. The actual sizes of the effects are of minor interest because the unit of the main explanatory variable "tax progressivity" is barely interpretable.

In specification $I$ we do not include any measure of tax progressivity and observe that the effects of the micro-level controls are in line with previous empirical analyses of tax morale (as discussed in section 2). Women and married people have greater tax morale than men and singles, respectively. Religiosity, patriotism and confidence in the state also have positive effects. Furthermore, compared to em- 
ployed individuals, we observe that being self-employed decreases tax morale, while being retired has a positive impact. When it comes to contextual-level variables, our analysis indicates that the "negative" variables "unemployment" and "inflation" have negative impacts on tax morale, whereas both "government expenditure" and the "top tax rate" have positive signs. The effective of "GDP per capita" is statistically significant as well.

We check the validity of our first hypothesis in specifications $I I$ and $I I I$. Independent of whether the top tax rate is included in the estimation $(I I I)$ or not $(I I)$, the effect of interest - $\mathrm{ARP}$ - is positive and highly significant. Controlling for a wide range of both individual-level and contextual-level variables, we thus reveal that tax morale is higher in countries with more progressive tax systems and are able to confirm our first hypothesis.

Table 1: Estimation Results

\begin{tabular}{|c|c|c|c|c|c|}
\hline & $I$ & $I I$ & $I I I$ & $I V$ & $V$ \\
\hline ARP (progressivity) & & $\begin{array}{l}6.129^{* * *} \\
(1.503)\end{array}$ & $\begin{array}{l}5.590^{* * *} \\
(2.048)\end{array}$ & $\begin{array}{l}8.474^{* * *} \\
(1.692)\end{array}$ & $\begin{array}{l}8.205^{* * *} \\
(2.168)\end{array}$ \\
\hline \multicolumn{6}{|l|}{ Interaction terms } \\
\hline ARP*Middle & & & & $\begin{array}{c}-2.275^{*} \\
(1.287)\end{array}$ & $\begin{array}{c}-2.267^{*} \\
(1.288)\end{array}$ \\
\hline ARP*Rich & & & & $\begin{array}{c}-6.098^{* * *} \\
(2.093)\end{array}$ & $\begin{array}{c}-6.064^{* * *} \\
(2.048)\end{array}$ \\
\hline Top tax rate & $\begin{array}{l}0.010^{* *} \\
(0.004)\end{array}$ & & $\begin{array}{c}0.002 \\
(0.006)\end{array}$ & & $\begin{array}{c}0.001 \\
(0.005)\end{array}$ \\
\hline \multicolumn{6}{|c|}{ Income group (Ref.: poor) } \\
\hline Middle & $\begin{array}{c}-0.066^{* *} \\
(0.032)\end{array}$ & $\begin{array}{c}-0.067^{* *} \\
(0.032)\end{array}$ & $\begin{array}{c}-0.067^{* *} \\
(0.032)\end{array}$ & $\begin{array}{c}0.105 \\
(0.112)\end{array}$ & $\begin{array}{c}0.104 \\
(0.113)\end{array}$ \\
\hline Rich & $\begin{array}{c}-0.192^{* * *} \\
(0.048)\end{array}$ & $\begin{array}{c}-0.190^{* * *} \\
(0.048)\end{array}$ & $\begin{array}{c}-0.190^{* * *} \\
(0.048)\end{array}$ & $\begin{array}{c}0.286 \\
(0.179)\end{array}$ & $\begin{array}{c}0.284 \\
(0.175)\end{array}$ \\
\hline Unemployment & $\begin{array}{c}-0.038^{* * *} \\
(0.011)\end{array}$ & $\begin{array}{c}-0.041^{* * *} \\
(0.012)\end{array}$ & $\begin{array}{c}-0.041^{* * *} \\
(0.011)\end{array}$ & $\begin{array}{c}-0.041^{* * *} \\
(0.011)\end{array}$ & $\begin{array}{c}-0.041^{* * *} \\
(0.011)\end{array}$ \\
\hline GDP per capita & $\begin{array}{c}-0.000^{* * *} \\
(0.000)\end{array}$ & $\begin{array}{c}-0.000^{* *} \\
(0.000)\end{array}$ & $\begin{array}{c}-0.000^{* *} \\
(0.000)\end{array}$ & $\begin{array}{c}-0.000^{* *} \\
(0.000)\end{array}$ & $\begin{array}{c}-0.000^{* *} \\
(0.000)\end{array}$ \\
\hline Inflation & $\begin{array}{c}-0.024^{* * *} \\
(0.006)\end{array}$ & $\begin{array}{c}-0.031^{* * *} \\
(0.007)\end{array}$ & $\begin{array}{c}-0.030^{* * *} \\
(0.006)\end{array}$ & $\begin{array}{c}-0.031^{* * *} \\
(0.006)\end{array}$ & $\begin{array}{c}-0.031^{* * *} \\
(0.006)\end{array}$ \\
\hline Government exp & $\begin{array}{l}0.087^{* * *} \\
(0.025)\end{array}$ & $\begin{array}{l}0.054^{* *} \\
(0.024)\end{array}$ & $\begin{array}{l}0.057^{* *} \\
(0.027)\end{array}$ & $\begin{array}{l}0.055^{* *} \\
(0.024)\end{array}$ & $\begin{array}{l}0.056^{* *} \\
(0.027)\end{array}$ \\
\hline Age & $\begin{array}{l}0.017^{* * *} \\
(0.001)\end{array}$ & $\begin{array}{l}0.017^{* * *} \\
(0.001)\end{array}$ & $\begin{array}{l}0.017^{* * *} \\
(0.001)\end{array}$ & $\begin{array}{l}0.017^{* * *} \\
(0.001)\end{array}$ & $\begin{array}{l}0.017^{* * *} \\
(0.001)\end{array}$ \\
\hline Education & $\begin{array}{c}-0.013^{* * *} \\
(0.005)\end{array}$ & $\begin{array}{c}-0.012^{* *} \\
(0.005)\end{array}$ & $\begin{array}{c}-0.013^{* *} \\
(0.005)\end{array}$ & $\begin{array}{c}-0.013^{* * *} \\
(0.005)\end{array}$ & $\begin{array}{c}-0.013^{* * *} \\
(0.005)\end{array}$ \\
\hline \multicolumn{6}{|l|}{ Gender (Ref.: male) } \\
\hline Female & $0.301^{* * *}$ & $0.299^{* * *}$ & $0.299^{* * *}$ & $\begin{array}{l}0.298^{* * *} \\
\text { continues }\end{array}$ & $\begin{array}{l}0.298^{* * *} \\
\text { next page }\end{array}$ \\
\hline
\end{tabular}




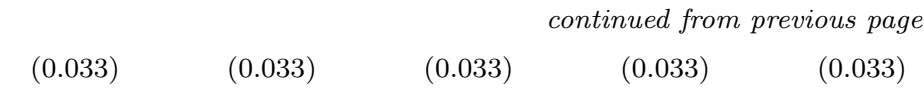

Employment Status (Ref.: employed)

\begin{tabular}{|c|c|c|c|c|c|}
\hline Self-employed & $\begin{array}{c}-0.176^{* * *} \\
(0.045)\end{array}$ & $\begin{array}{c}-0.172^{* * *} \\
(0.046)\end{array}$ & $\begin{array}{c}-0.173^{* * *} \\
(0.045)\end{array}$ & $\begin{array}{c}-0.176^{* * *} \\
(0.046)\end{array}$ & $\begin{array}{c}-0.176^{* * *} \\
(0.045)\end{array}$ \\
\hline \multirow[t]{2}{*}{ Retired } & $0.146^{* * *}$ & $0.144^{* * *}$ & $0.145^{* * *}$ & $0.137^{* * *}$ & $0.138^{* * *}$ \\
\hline & $(0.039)$ & $(0.038)$ & $(0.038)$ & $(0.039)$ & $(0.038)$ \\
\hline \multirow[t]{2}{*}{ Unemployed } & -0.055 & -0.056 & -0.056 & -0.059 & -0.059 \\
\hline & $(0.053)$ & $(0.053)$ & $(0.053)$ & $(0.053)$ & $(0.053)$ \\
\hline \multirow[t]{2}{*}{ Other } & 0.036 & 0.039 & 0.039 & 0.035 & 0.035 \\
\hline & $(0.044)$ & $(0.044)$ & $(0.044)$ & $(0.044)$ & $(0.044)$ \\
\hline \multicolumn{6}{|c|}{ Religiosity (Ref.: church attendance less than once a month) } \\
\hline \multirow[t]{2}{*}{ Monthly/>monthly } & $0.286^{* * *}$ & $0.290^{* * *}$ & $0.289^{* * *}$ & $0.289^{* * *}$ & $0.289^{* * *}$ \\
\hline & $(0.044)$ & $(0.044)$ & $(0.044)$ & $(0.044)$ & $(0.044)$ \\
\hline \multicolumn{6}{|c|}{ Marital Status (Ref.: single/never married) } \\
\hline \multirow[t]{2}{*}{ Divorced/separated } & 0.023 & 0.022 & 0.022 & 0.024 & 0.025 \\
\hline & $(0.050)$ & $(0.050)$ & $(0.050)$ & $(0.050)$ & $(0.050)$ \\
\hline \multirow[t]{2}{*}{ Married/as married } & $0.144^{* * *}$ & $0.143^{* * *}$ & $0.143^{* * *}$ & $0.149^{* * *}$ & $0.149^{* * *}$ \\
\hline & $(0.037)$ & $(0.037)$ & $(0.037)$ & $(0.036)$ & $(0.036)$ \\
\hline \multicolumn{6}{|c|}{ Patriotism (Ref.: not at all proud/not proud) } \\
\hline \multirow[t]{2}{*}{ Very/quite proud } & $0.311^{* * *}$ & $0.314^{* * *}$ & $0.314^{* * *}$ & $0.313^{* * *}$ & $0.313^{* * *}$ \\
\hline & $(0.070)$ & $(0.071)$ & $(0.071)$ & $(0.070)$ & $(0.070)$ \\
\hline \multicolumn{6}{|c|}{ Confidence in the state (Ref.: little/none) } \\
\hline \multirow[t]{2}{*}{ quite a lot/a lot } & $0.152^{* * *}$ & $0.150^{* * *}$ & $0.151^{* * *}$ & $0.152^{* * *}$ & $0.152^{* * *}$ \\
\hline & $(0.031)$ & $(0.031)$ & $(0.031)$ & $(0.031)$ & $(0.031)$ \\
\hline \multirow[t]{2}{*}{ constant } & $-2.562^{* * *}$ & $-1.854^{* * *}$ & $-1.997^{* * *}$ & $-2.040^{* * *}$ & $-2.108^{* * *}$ \\
\hline & $(0.632)$ & $(0.446)$ & $(0.626)$ & $(0.452)$ & $(0.620)$ \\
\hline Wave dummies & yes & yes & yes & yes & yes \\
\hline Country dummies & yes & yes & yes & yes & yes \\
\hline Individual Obs. & 50947 & 50947 & 50947 & 50947 & 50947 \\
\hline Contextual Obs. & 50 & 50 & 50 & 50 & 50 \\
\hline Pseudo $R^{2}$ & 0.0737 & 0.0739 & 0.0739 & 0.0742 & 0.0742 \\
\hline AIC & 64686.57 & 64669.64 & 64671.23 & 64655.91 & 64657.82 \\
\hline BIC & 65048.95 & 65032.02 & 65042.45 & 65035.97 & 65046.71 \\
\hline chi2 & 70577.015 & 11447.131 & 16527.132 & 14691.549 & 19901.259 \\
\hline $\mathrm{p}$ & 0.000 & 0.000 & 0.000 & 0.000 & 0.000 \\
\hline
\end{tabular}

[1] Dependent Variable: Tax Morale (Dummy with 1 "high", 0 "otherwise") [2] Logistic regression [3] Coefficients reported [4] Cluster adjusted, robust standard errors in parentheses [5] Ref. =Reference Category [6] $* p<0.10, * * p<0.05, * * * p<0.01$

Our second hypothesis is overhauled in specifications $I V$ and $V$, where we add interaction terms between ARP and the income groups. As expected, the impact of progressive taxation is the highest among the poor - indicated by the coefficient on ARP in $I V$ and $V$, and the lowest among the richest individuals - measured through 
the coefficient on ARP plus the negative coefficient on $A R P *$ Rich. Both effects are highly significant and, once again, do not depend on the inclusion of the top tax rate. The impact among middle-class individuals lies in between and is significant at the $10 \%$ level.

\subsection{Robustness Checks}

A bivariate analysis (not reported) finds Japan to have both the highest levels of progressivity and tax morale. Concerned that Japan might influence our results in the "right" direction, we remove the outlier from our analysis in a robustness check to test the validity of our results. Table 6 in the appendix indicates that our results remain stable through all specifications. Although we have excluded the country with the highest values for both tax morale and progressivity, progressivity still has a significant and positive impact on tax morale. In order to further establish the link between tax morale and progressivity, we ran a probit model instead of the logistic regression. The results - presented in table 6 the appendix - show that our original results remain unaffected. Moreover, our results are robust to different operationalizations of the control variables as well. This is especially true for the income variable, as it does not change any implications when we use the 10-step income variable originally provided in the WVS, be it on a continuous scale or using dummies for each decile.

\section{Conclusion}

Understanding determinants of tax morale is an important piece of the puzzle in order to explain why people pay taxes, and it can help to fight tax evasion. In this study we investigated the impact of progressive taxes on tax morale - a link that has so far been absent in the literature. Our theoretical analysis shows that an individual's tax morale is higher, the more progressive the tax schedule is, and that the impact of tax progressivity with tax morale is declining in income. Testing these hypotheses empirically, we do indeed reveal a positive (and declining) association between progressive taxation and tax morale, suggesting that tax evasion is less in systems with high degrees of progressivity.

Our analysis has implications for public policy makers. In the public and media discussion, progressive taxes are often considered to be damaging from an economic point of view, as they harm incentives and burden a society's high performers with too high taxes. We are able to show, however, that tax progressivity might also yield positive economic outcomes. Even when holding the income constant, it was 
shown that taxpayers are willing to sacrifice some of their income in order to install a more equal after-tax distribution. Progressive taxes, therefore, contribute to less tax evasion and higher perceived fairness and equality. Note, however, that we are not able to identify a causal relationship. The causality could also go the other way: because of higher tax morale (and inequality aversion) of their citizens, the governments can c.p. impose higher taxes with higher degrees of progressivity.

Although shown to have high significance, research on the determinants of tax morale is as yet insufficient. While individual-level factors explaining different levels of tax morale have been analyzed quite frequently, literature on contextuallevel factors is not satisfactory. Further research has to investigate the standard economical determinants of tax evasion, such as tax rates and penalties for evading. Furthermore, the impacts of different types of income tax systems and of indirect taxes such as VAT on tax morale have to be considered-ideally in extensive crosscountry approaches. More research also has to devote itself to establish further the link between tax morale measured in surveys and actual compliance behavior. 


\section{A Appendix}

Table 2: Operationalization of Included Variables

\begin{tabular}{|c|c|c|}
\hline Variable & Source & Operationalization \\
\hline Tax Morale & WVS & Tax evasion justified? Other (Ref.), never \\
\hline $\begin{array}{l}\text { Progressivity } \\
\text { ARP }\end{array}$ & WTI & $\begin{array}{l}\text { Coefficient from regressing average tax rates for } \\
\text { different incomes within one country on income } \\
\text { (continuous scale) }\end{array}$ \\
\hline Gender & WVS & Male (Ref.), female \\
\hline Age & WVS & Age in years \\
\hline Marital Status & WVS & $\begin{array}{l}\text { Single/never married (Ref.), divorced/separated, } \\
\text { married/living together as married }\end{array}$ \\
\hline $\begin{array}{l}\text { Employment } \\
\text { Status }\end{array}$ & WVS & $\begin{array}{l}\text { Employed (Ref.), self-employed, pensioner, unem- } \\
\text { ployed, other }\end{array}$ \\
\hline Education & WVS & Education in years \\
\hline Income groups & WVS & $\begin{array}{l}3 \text { income groups: poor (Ref.), middle, rich (derived } \\
\text { from } 10 \text { step income variable) }\end{array}$ \\
\hline Patriotism & WVS & $\begin{array}{l}\text { How proud to be [respective nationality]? Not at } \\
\text { all/not very proud (Ref.), very/quite proud }\end{array}$ \\
\hline Religiosity & WVS & $\begin{array}{l}\text { Frequency of church attendances: Less than once } \\
\text { a month (Ref.), more than once a month }\end{array}$ \\
\hline $\begin{array}{l}\text { Confidence in } \\
\text { the State }\end{array}$ & WVS & $\begin{array}{l}\text { Could you tell me how much confidence you have in } \\
\text { the parliament? Little/none (Ref.), quite a lot/a } \\
\text { lot }\end{array}$ \\
\hline Top Tax Rate & WTI & $\begin{array}{l}\text { Tax rate applicable to the highest income bracket } \\
\text { in each country }\end{array}$ \\
\hline Unemployment & World Bank & Total unemployment rate as $\%$ of total labor force \\
\hline Inflation & World Bank & Annual inflation of consumer prices in $\%$ \\
\hline GDP per capita & World Bank & GDP per capita in $\$$ \\
\hline $\begin{array}{l}\text { Government Ex- } \\
\text { penditure }\end{array}$ & World Bank & General government expenditure as \% of GDP \\
\hline $\begin{array}{l}\text { Country Dum- } \\
\text { mies }\end{array}$ & / & Dummies for each country but one \\
\hline Wave Dummies & / & Dummies for each wave but one \\
\hline
\end{tabular}

Ref. = Reference category 
Table 3: Number of Observations by Country and Wave

\begin{tabular}{lllll|l}
\hline \hline \multirow{2}{*}{ Country } & \multicolumn{5}{c}{ Wave } \\
\cline { 2 - 4 } Austria & $1981-1984$ & $1989-1993$ & $1994-1999$ & $1999-2004$ & Total \\
Belgium & 0 & 1,222 & 0 & 1,084 & 2,306 \\
Canada & 0 & 1,436 & 0 & 1,180 & 2,616 \\
Denmark & 939 & 1,360 & 0 & 1,340 & 3,639 \\
Finland & 0 & 784 & 0 & 817 & 1,601 \\
France & 0 & 479 & 784 & 763 & 2,026 \\
Germany & 735 & 646 & 0 & 1,106 & 2,487 \\
Hungary & 0 & 2,733 & 0 & 1,330 & 4,063 \\
Iceland & 0 & 914 & 0 & 853 & 1,767 \\
Ireland & 0 & 468 & 0 & 755 & 1,223 \\
Italy & 0 & 856 & 0 & 752 & 1,608 \\
Japan & 787 & 1,320 & 0 & 1,387 & 2,707 \\
Mexico & 0 & 591 & 763 & 921 & 3,062 \\
Netherlands & 0 & 339 & 1,509 & 765 & 2,613 \\
Norway & 900 & 698 & 0 & 841 & 1,539 \\
Spain & 1,826 & 2,410 & 660 & 1,352 & 2,696 \\
Sweden & 697 & 0 & 789 & 701 & 6,248 \\
United Kingdom & 0 & 1,016 & 0 & 522 & 2,187 \\
United States & 1,849 & 1,443 & 863 & 866 & 5,021 \\
\hline Total & 7,733 & 19,572 & 6,307 & 17,335 & 50,947 \\
\hline \hline
\end{tabular}


Table 4: Summary Statistics of Included Continuous and Dummy Variables

\begin{tabular}{lllll}
\hline \hline Variable & Mean & Std. Dev. & Min & Max \\
\hline $\begin{array}{l}\text { Tax morale dummy } \\
\text { (1: high tax morale) }\end{array}$ & 0.5657 & 0.4957 & 0 & 1 \\
Progressivity ARP & 0.0780 & 0.0192 & 0.0415 & 0.1445 \\
Gender dummy & 0.5069 & 0.4999 & 0 & 1 \\
(1: female) & & & & \\
Education in years & 11.7947 & 4.0396 & 1 & 24 \\
Patriotism & 0.8641 & 0.3427 & 0 & 1 \\
(1: very/quite proud) & & & & \\
Age & 44.3306 & 16.7017 & 19 & 100 \\
Confidence in state & 0.4327 & 0.4955 & 0 & 1 \\
(1: quite a lot/a lot) & & & & \\
Unemployment rate & 7.9237 & 4.1858 & 2 & 22.7 \\
GDP per capita & 20209.14 & 8766.966 & 3156.583 & 41833.96 \\
Inflation & 6.1792 & 7.5177 & -0.7122 & 34.3777 \\
Government expenditure & 18.7143 & 4.1698 & 8.3840 & 29.4132 \\
Top tax rate & 44.7273 & 13.0327 & 12 & 75 \\
\hline \hline
\end{tabular}

$N=50,947$ individual observations included in analysis

Std. Dev. = Standard Deviation 
Table 5: Summary Statistics of Included Classified Variables

\begin{tabular}{lll}
\hline \hline Income Groups & Frequency & Percent \\
\hline Poor & 15,509 & 30.44 \\
Middle & 24,717 & 48.52 \\
Rich & 10,721 & 21.04 \\
\hline Total & 50,947 & 100.00 \\
& & \\
Marital Status & Frequency & Percent \\
\hline Single & 10,407 & 20.43 \\
Separated or widowed & 6,893 & 13.53 \\
Married or as married & 33,647 & 66.05 \\
\hline Total & 50,947 & 100.00 \\
& & \\
Employment Status & Frequency & Percent \\
\hline Employed & 26,957 & 52.91 \\
Self-employed & 3,433 & 6.56 \\
Retired & 8,753 & 17.18 \\
Unemployed & 2,552 & 5.01 \\
Other & 9,342 & 18.34 \\
\hline Total & 50,947 & 100.00 \\
\hline \hline
\end{tabular}


Table 6: Robustness Check: Probit estimation/excluding Japan

\begin{tabular}{|c|c|c|c|c|}
\hline & ProbitI & ProbitII & $\begin{array}{r}\text { ExclJapI } \\
(\text { logit })\end{array}$ & $\begin{array}{r}\text { ExclJapII } \\
(\text { logit })\end{array}$ \\
\hline ARP (progressivity) & $\begin{array}{l}3.458^{* * *} \\
(1.262)\end{array}$ & $\begin{array}{l}5.068^{* * *} \\
(1.323)\end{array}$ & $\begin{array}{l}5.461^{* * *} \\
(1.959)\end{array}$ & $\begin{array}{l}8.031^{* * *} \\
(2.103)\end{array}$ \\
\hline \multicolumn{5}{|l|}{ Interaction terms } \\
\hline ARP*Middle & & $\begin{array}{r}-1.391^{*} \\
(0.779)\end{array}$ & & $\begin{array}{r}-2.299^{*} \\
(1.307)\end{array}$ \\
\hline ARP*Rich & & $\begin{array}{c}-3.795^{* * *} \\
(1.231)\end{array}$ & & $\begin{array}{c}-5.748^{* * *} \\
(2.115)\end{array}$ \\
\hline Top tax rate & $\begin{array}{c}0.001 \\
(0.003)\end{array}$ & $\begin{array}{c}0.000 \\
(0.003)\end{array}$ & $\begin{array}{c}0.007 \\
(0.006)\end{array}$ & $\begin{array}{c}0.005 \\
(0.006)\end{array}$ \\
\hline \multicolumn{5}{|c|}{ Income group (Ref.: poor) } \\
\hline Middle & $\begin{array}{c}-0.041^{* *} \\
(0.020)\end{array}$ & $\begin{array}{c}0.065 \\
(0.068)\end{array}$ & $\begin{array}{c}-0.070^{* *} \\
(0.033)\end{array}$ & $\begin{array}{c}0.104 \\
(0.113)\end{array}$ \\
\hline Rich & $\begin{array}{c}-0.117^{* * *} \\
(0.029)\end{array}$ & $\begin{array}{c}0.180^{*} \\
(0.106)\end{array}$ & $\begin{array}{c}-0.196^{* * *} \\
(0.050)\end{array}$ & $\begin{array}{c}0.254 \\
(0.182)\end{array}$ \\
\hline Unemployment & $\begin{array}{c}-0.025^{* * *} \\
(0.007)\end{array}$ & $\begin{array}{c}-0.025^{* * *} \\
(0.007)\end{array}$ & $\begin{array}{c}-0.045^{* * *} \\
(0.010)\end{array}$ & $\begin{array}{c}-0.045^{* * *} \\
(0.010)\end{array}$ \\
\hline GDP per capita & $\begin{array}{c}-0.000^{* *} \\
(0.000)\end{array}$ & $\begin{array}{c}-0.000^{* *} \\
(0.000)\end{array}$ & $\begin{array}{c}-0.000^{* *} \\
(0.000)\end{array}$ & $\begin{array}{c}-0.000^{* * *} \\
(0.000)\end{array}$ \\
\hline Inflation & $\begin{array}{c}-0.019^{* * *} \\
(0.004)\end{array}$ & $\begin{array}{c}-0.019 * * * \\
(0.004)\end{array}$ & $\begin{array}{c}-0.033^{* * *} \\
(0.007)\end{array}$ & $\begin{array}{c}-0.033^{* * *} \\
(0.006)\end{array}$ \\
\hline Government exp. & $\begin{array}{l}0.036^{* *} \\
(0.016)\end{array}$ & $\begin{array}{l}0.035^{* *} \\
(0.016)\end{array}$ & $\begin{array}{c}0.050 * \\
(0.026)\end{array}$ & $\begin{array}{c}0.050^{*} \\
(0.026)\end{array}$ \\
\hline Age & $\begin{array}{l}0.010^{* * *} \\
(0.001)\end{array}$ & $\begin{array}{l}0.010^{* * *} \\
(0.001)\end{array}$ & $\begin{array}{l}0.016^{* * *} \\
(0.001)\end{array}$ & $\begin{array}{l}0.016^{* * *} \\
(0.001)\end{array}$ \\
\hline Education & $\begin{array}{c}-0.008^{* *} \\
(0.003)\end{array}$ & $\begin{array}{c}-0.008^{* * *} \\
(0.003)\end{array}$ & $\begin{array}{c}-0.012^{* *} \\
(0.005)\end{array}$ & $\begin{array}{c}-0.012^{* *} \\
(0.005)\end{array}$ \\
\hline \multicolumn{5}{|l|}{ Gender (Ref.: male) } \\
\hline Female & $\begin{array}{l}0.183^{* * *} \\
(0.020)\end{array}$ & $\begin{array}{l}0.183^{* * *} \\
(0.020)\end{array}$ & $\begin{array}{l}0.303^{* * *} \\
(0.034)\end{array}$ & $\begin{array}{l}0.303^{* * *} \\
(0.034)\end{array}$ \\
\hline \multicolumn{5}{|c|}{ Employment Status (Ref.: employed) } \\
\hline Self-employed & $\begin{array}{c}-0.107^{* * *} \\
(0.028)\end{array}$ & $\begin{array}{c}-0.109^{* * *} \\
(0.028)\end{array}$ & $\begin{array}{c}-0.155^{* * *} \\
(0.047)\end{array}$ & $\begin{array}{c}-0.159^{* * *} \\
(0.047)\end{array}$ \\
\hline Retired & $\begin{array}{l}0.087^{* * *} \\
(0.023)\end{array}$ & $\begin{array}{l}0.083^{* * *} \\
(0.024)\end{array}$ & $\begin{array}{l}0.152^{* * *} \\
(0.039)\end{array}$ & $\begin{array}{l}0.144^{* * *} \\
(0.039)\end{array}$ \\
\hline Unemployed & $\begin{array}{r}-0.036 \\
(0.033)\end{array}$ & $\begin{array}{r}-0.038 \\
(0.033)\end{array}$ & $\begin{array}{r}-0.044 \\
(0.053)\end{array}$ & $\begin{array}{r}-0.047 \\
(0.053)\end{array}$ \\
\hline Other & $\begin{array}{c}0.024 \\
(0.026)\end{array}$ & $\begin{array}{c}0.022 \\
(0.027)\end{array}$ & $\begin{array}{c}0.027 \\
(0.045)\end{array}$ & $\begin{array}{c}0.023 \\
(0.045)\end{array}$ \\
\hline \multicolumn{5}{|c|}{ Religiosity (Ref.: church attendance less than once a month) } \\
\hline Monthly/>monthly & $\begin{array}{c}0.176^{* * *} \\
(0.026)\end{array}$ & $\begin{array}{l}0.176^{* * *} \\
(0.026)\end{array}$ & $\begin{array}{l}0.295^{* * *} \\
(0.045)\end{array}$ & $\begin{array}{l}0.295^{* * *} \\
(0.045)\end{array}$ \\
\hline \multicolumn{5}{|c|}{ Marital Status (Ref.: single/never married) } \\
\hline Divorced/separated & 0.014 & 0.016 & 0.016 & 0.018 \\
\hline
\end{tabular}




\begin{tabular}{lcccc} 
& & & \multicolumn{2}{c}{ continued from previous page } \\
& $(0.031)$ & $(0.030)$ & $(0.050)$ & $(0.050)$ \\
Married/as married & $0.089^{* * *}$ & $0.093^{* * *}$ & $0.136^{* * *}$ & $0.142^{* * *}$ \\
& $(0.023)$ & $(0.022)$ & $(0.037)$ & $(0.036)$ \\
Patriotism (Ref.: not at all proud/not proud) & & & \\
Very/quite proud & $0.189^{* * *}$ & $0.189^{* * *}$ & $0.352^{* * *}$ & $0.351^{* * *}$ \\
& $(0.043)$ & $(0.043)$ & $(0.074)$ & $(0.074)$ \\
Confidence in the state & Ref.: little/none) & & & $0.154^{* * *}$ \\
quite a lot/a lot & $0.092^{* * *}$ & $0.093^{* * *}$ & $0.152^{* * *}$ & $(0.032)$ \\
& $(0.019)$ & $(0.019)$ & $(0.032)$ & $-2.142^{* * *}$ \\
constant & $-1.216^{* * *}$ & $-1.283^{* * *}$ & $-2.031^{* * *}$ & $(0.617)$ \\
& $(0.385)$ & $(0.380)$ & $(0.619)$ & $y e s$ \\
Wave dummies & $y e s$ & $y e s$ & $y e s$ & $y e s$ \\
Country dummies & $y e s$ & $y e s$ & $y e s$ & 47885.000 \\
\hline Individual Obs. & 50947.000 & 50947.000 & 47885.000 & 46 \\
Contextual Obs. & 50 & 50 & 46 & 0.0629 \\
Pseudo $R^{2}$ & 0.0738 & 0.0741 & 0.0626 & 61862.87 \\
AIC & 64680.85 & 64666.59 & 61873.82 & 62240.26 \\
BIC & 65052.07 & 65055.48 & 62233.66 & $4.17 e+05$ \\
chi2 & 17412.506 & 21178.920 & 45632.296 & 0.000 \\
p & 0.000 & 0.000 & 0.000 & \\
\hline \hline
\end{tabular}

[1] Dependent Variable: Tax Morale (Dummy with 1 "high", 0 "otherwise")

[2] Coefficients reported [4] Cluster adj, robust standard errors in parentheses

[4] Ref. $=$ Reference [5] $* p<0.10, * * p<0.05, * * * p<0.01$ 


\section{References}

Ackert, L. F., J. Martinez-Vazquez, and M. Rider (2007). Social preferences and tax policy design: Some experimental evidence. Economic Inquiry 45(3), 487 $-501$.

Alesina, A., R. Di Tella, and R. MacCulloch (2004). Inequality and happiness: Are Europeans and Americans different? Journal of Public Economics 88(9-10), $2009-2042$.

Alesina, A. F. and P. Giuliano (2009). Preferences for redistribution. NBER Working paper 14825 and forthcoming in Handbook for Social Economics.

Allingham, M. G. and A. Sandmo (1972). Income tax evasion: A theoretical analysis. Journal of Public Economics 1(3-4), 323 - 338.

Alm, J. and J. L. Gomez (2008). Social capital and tax morale in Spain. Economic Analysis 8 Policy 38(1), $73-87$.

Alm, J., J. Martinez-Vazque, and B. Torgler (2006). Russian attitudes toward paying taxes - before, during, and after the transition. International Journal of Social Economics 33(12), 832 - 857.

Alm, J., G. H. McClelland, and W. D. Schulze (1992). Why do people pay taxes? Journal of Public Economics 48(1), 21 - 38.

Alm, J. and B. Torgler (2006). Culture differences and tax morale in the United States and in Europe. Journal of Economic Psychology 27(2), 224 - 246.

Andreoni, J., B. Erard, and J. Feinstein (1998). Tax compliance. Journal of Economic Literature 36(2), $818-860$.

Becker, G. S. (1968). Crime and punishment: An economic approach. The Journal of Political Economy 76(2), 169 - 217.

Bellemare, C., S. Kroeger, and A. v. Soest (2008). Measuring inequity aversion in a heterogeneous population using experimental decisions and subjective probabilities. Econometrica 76(4), 815 - 839.

Corneo, G. and H. P. Gruener (2002). Individual preferences for political redistribution. Journal of Public Economics 83(1), 83 - 107.

Cummings, R. G., J. Martinez-Vazquez, M. McKee, and B. Torgler (2009). Tax morale affects tax compliance: Evidence from surveys and an artefactual field experiment. Journal of Economic Behavior $\&$ Organization 70(3), 447 - 457.

Dell'Anno, R. (2009). Tax evasion, tax morale and policy maker's effectiveness. The Journal of Socio-Economics 38(6), 988 - 997. 
Eckel, C. and H. Gintis (2010). Blaming the messenger: Notes on the current state of experimental economics. Journal of Economic Behavior \&5 Organization $73(1), 109-119$.

Elffers, H., R. H. Weigel, and D. J. Hessing (1987). The consequences of different strategies for measuring tax evasion behavior. Journal of Economic Psychology $8(3), 311-337$.

Erard, B. and J. S. Feinstein (1994). The role of moral sentiment and audit perceptions in tax compliance. Public Finance 49 (Supplement), $70-89$.

EVS/WVS (2006). European and World Values Surveys four-wave integrated data file, 1981-2004. Surveys designed and executed by the European Values Study Group and World Values Survey Association. http://worldvaluessurvey. org/ (accessed June 2010).

Fehr, E. and K. M. Schmidt (1999). A theory of fairness, competition, and cooperation. The Quarterly Journal of Economics 114(3), 817 - 868.

Fehr, E. and K. M. Schmidt (2006). The economics of fairness, reciprocity and altruism - Experimental evidence and new theories. In S.-C. Kolm and J. M. Ythier (Eds.), Foundations, Volume 1 of Handbook on the Economics of Giving, Altruism and Reciprocity, pp. 615 - 691. Amsterdam, Netherlands: Elsevier.

Feld, L. P. and B. S. Frey (2007). Tax compliance as the result of a pychological tax contract: The role of incentives and responsive regulation. Law $\&$ Policy 29(1), $102-120$.

Fong, C. (2001). Social preferences, self-interest, and the demand for redistribution. Journal of Public Economics 82(2), 225 - 246.

Frey, B. S. and L. P. Feld (2002). Deterrence and morale in taxation. CESifo Working Paper No. 760.

Frey, B. S. and B. Torgler (2007). Tax morale and conditional cooperation. Journal of Comparative Economics 35(1), 136 - 159.

Gueth, W., R. Schmittberger, and B. Schwarze (1982). An experimental analysis of ultimatum bargaining. Journal of Economic Behavior $\&$ Organization 3(4), $367-388$.

Halla, M. (2010). Tax morale and compliance behavior: First evidence on a causal link. Johannes Kepler University of Linz Working Paper No. 1066.

Heinemann, F. (2010). Economic crisis and morale. European Journal of Law and Economics, $1-15$. 
Heinemann, F. and T. Hennighausen (2010). Don't tax me? Determinants of individuals towards progressive taxation. ZEW Discussion paper No. 10-017.

Heinemann, F. and M. G. Kocher (2010). Tax compliance under tax regime changes. Munich Discussion Paper 2010-17.

Hull, B. B. (2000). Religion still matters. The Journal of Economics 26(2), 35 48.

Inglehart, R. (2000). Codebook for World Values Survey. Ann Arbor, USA: Institute for Social Research.

Inglehart, R. (n.d.). Values change the world. http://worldvaluessurvey.org/ (accessed April 2010).

Kahneman, D., J. Knetsch, and R. H. Thaler (1986). Fairness as a constraint on profit seeking: Entitlements in the market. The American Economic Review $76(4), 728-741$.

Konow, J. (2003). Which is the fairest one of all? A positive analysis of justice theories. Journal of Economic Literature 41(4), 1188 - 1239.

Konrad, K. A. and S. Qari (2009). The last refuge of a scoundrel? Patriotism and tax compliance. IZA Discussion paper Series No. 4121.

Martinez-Vazquez, J. and B. Torgler (2009). The evolution of tax morale in modern Spain. Journal of Economic Issues 43(1), 1 - 28.

McKinnish, T. (2007). Welfare-induced migration at state borders: New evidence from micro-data. Journal of Public Economics 91(3-4), 437 - 450.

Moulton, B. R. (1986). Random group effects and the precision of regression estimates. Journal of Econometrics 32(3), 385 - 397.

Peter, K. S., P. Buttrick, and D. Duncan (2010). Global reform of personal income taxation, 1981-2005: Evidence from 189 countries. National Tax Journal $63(3), 447-478$.

Pommerehne, W. W. and H. Weck-Hannemann (1996). Tax rates, tax administration and income tax evasion in Switzerland. Public Choice 88(1-2), 161 170.

Richardson, G. (2006). Determinants of tax evasion: A cross-country investigation. Journal of International Accounting, Auditing and Taxation 15(2), 150 -169 .

Slemrod, J. (2003). Trust in public finance. In S. Cnossen and H.-W. Sinn (Eds.), Public Finance and Public Policy in the New Century, pp. 49 - 88. Cambridge, USA: The MIT Press. 
Slemrod, J. (2007). Cheating ourselves: The economics of tax evasion. Journal of Economic Perspectives 21(1), 25 - 48.

Slemrod, J. and S. Yitzhaki (2002). Tax avoidance, evasion, and administration. In A. J. Auerbach and M. Feldstein (Eds.), n.a., Volume 3 of Handbook of Public Economics, pp. 1423 - 1470. Amsterdam, Netherlands: Elsevier.

Tittle, C. (1980). Sanctions and Social Deviance: The question of deterrence. New York, USA: Praeger.

Torgler, B. (2002). Speaking to theorists and searching for facts: Tax morale and tax compliance in experiments. Journal of Economic Surveys 16(5), 657 683.

Torgler, B. (2004). Tax morale in Asian countries. Journal of Asian Economics 15(2), $237-266$.

Torgler, B. (2005). Tax morale in Latin America. Public Choice 122(1-2), 133 157.

Torgler, B. (2006). The importance of faith: Tax morale and religiosity. Journal of Economic Behavior \&5 Organization 61(1), 81 - 109.

Torgler, B. (2007). Tax Compliance and Tax Morale: A Theoretical and Empirical Analysis. Cheltenham, UK: Edward Elgar.

Torgler, B., I. C. Demir, A. Macintyre, and M. Schaffner (2008). Causes and consequences of tax morale: An empirical investigation. Economic Analysis and Policy (EAP) 38(2), $313-339$.

Torgler, B. and F. Schneider (2009). The impact of tax morale and institutional quality on the shadow economy. Journal of Economic Psychology 30(2), 228 -245 .

World Bank (2010). The Word Development Indicators. http://databank. worldbank. org/ (accessed June 2010).

Wu, S.-Y. and M.-J. Teng (2005). Determinants of tax compliance. A crosscountry analysis. FinanzArchiv 61(3), $393-417$. 